\title{
Assessing Carl Strehlow's dictionary as linguistic description: Present value and future potential
}

\author{
John Henderson
}

\section{Introduction}

The extent and quality of Carl Strehlow's comparative dictionary makes it an extraordinary work for its time, and in some ways it remains so by current standards. The sheer number of entries-around 7,600-is impressive, and for its time it demonstrates a reasonably sophisticated attempt to characterise meanings. This chapter primarily considers the dictionary as a work of language description - in terms of the analytical concepts of linguistics and the methods of modern lexicography. Understanding the value and limitations of Strehlow's dictionary in these ways provides an appreciation of his achievements in the dictionary, its place in relation to other current Aranda ${ }^{1}$ and Luritja language resources, and perhaps most importantly its potential contribution to new resources for these languages.

\footnotetext{
1 Strehlow's spelling 'Aranda' is used in this chapter, except where it is necessary to distinguish the two modern orthographies of Western Aranda in recent published works.
} 
The first section gives a brief overview of the nature of the dictionary. It considers the context from which the dictionary arose, its contribution to more recent work, and the languages that are represented in it. The next section looks at the basic organisation of information into entries in the dictionary. The following sections then focus in detail on the important grammatical information in different types of entries, and the strategies for characterising meaning. The representation of Aranda sounds in the dictionary is discussed here only as it relates to lexicographical and grammatical matters. The accompanying chapter on the Mission Orthography provides a fuller discussion. The analytical concepts of linguistics used in this chapter are introduced for a broader readership at the relevant points.

\section{Overview}

The dictionary is examined here as a work in its own right although it is just one component of Strehlow's overall descriptive work. He also collected and documented numerous traditional texts from Aranda and Luritja people, and wrote an analysis of the grammar and other materials (which include an account of Aranda sign language). The collection of texts is particularly significant because texts can provide a wide range of words and expressions used in a range of contexts - necessary information for a high-quality dictionary. His intellectual work in translating texts from Aranda and Luritja, and in translating Christian materials into these languages, must also have contributed to a sophisticated analysis of the grammar and lexicon of both languages. His dictionary can be evaluated for the accuracy, range and depth of its description of the lexicon, and like any other work of language description those things should be evaluated in terms of the author's goals and methods, and the goals of its audience, and in terms of the principles and practices in language description. For modern readers of the dictionary, it is important to understand the nature of the work in order to interpret the individual entries. It is presented in this volume in a publication format like other modern dictionaries, but the content is not a final version ready for publication. It is a handwritten draft which has many inconsistencies and limitations, and interpreting entries is not always straightforward. 
As a historical work the dictionary is a record of the language at an earlier point in time. It both documents the local community's language heritage and offers an understanding of the paths of language change over a period of enormous social change. It is clear that today's Aranda and Luritja are fundamentally the same as the languages of Strehlow's time, but as speakers today get the chance to work through this dictionary it will become clearer how much of the 'old language' has changed or been lost. Some words in the dictionary have not been recognised by those Aranda speakers who have had a chance so far to make their own evaluation, though not all these cases necessarily indicate change or loss in the languages. Strehlow's spelling of the Aranda and Luritja words is in many ways not specific enough to indicate which of the sounds of these languages actually occurs in a given word. His definitions vary widely in detail but are mostly only simple glosses in German, and as useful as they may be, we can see from comparison with modern dictionaries that producing a fuller account of the meaning of a word requires a more developed approach. So in some cases, even very knowledgeable speakers might not recognise Strehlow's entry for a word they actually know. In the cases where speakers actually do not already know the word, it is not straightforward to work out how that word was pronounced and what its precise meaning was.

Strehlow's description of the Western Aranda language was preceded by the impressive work of Hermann Kempe, his missionary predecessor at Hermannsburg 1876-91 and a founder of the mission. Kempe's grammatical description and vocabulary was published in 1891. It seems reasonable to assume that Strehlow was influenced by and benefited from Kempe's work, though it is clear from the much greater size of Strehlow's dictionary that he was seeking a much fuller and more detailed coverage of the vocabulary, and must have developed a deep knowledge of the language. Modern experience in producing dictionaries means we can be confident that Strehlow's dictionary was at enormous expense in terms of time and effort. For one thing, it is significant that it is a large handwritten list that is mostly alphabetically ordered, because this must have been preceded by a method of collecting individual words over time before they could be collated into an ordered list. It may be that he used a common method of starting off with a paper slip for each entry as the word was recorded, and inserting it into the stack of slips at the right place in the alphabetical order. By any method though, the task was enormous in a pre-computer age. Given that the practical aspects of his everyday life in the early mission were very demanding (Lohe 1977), his linguistic and cultural description is an even greater achievement. 
This volume describes Strehlow's work as a heritage dictionary. This term recognises not just that it has value as part of Aranda and Luritja history, it recognises that the dictionary is a work of its time and context. People looking for a dictionary of the languages today have a range of modern resources available in the current orthographies. The Western Arrarnta Picture Dictionary (Roennfeldt et al. 2006) is a school language resource, in the modern orthography used in school programs and some other contexts in the Hermannsburg area. The Introductory Dictionary of Western Arrernte (Breen et al. 2000) is in the alternative modern orthography that was used for some years at Yipirinya School in Alice Springs. ${ }^{2}$ The Pintupil Luritja Dictionary (Hansen and Hansen 1992) is an extensive dictionary of the Western Dialects adjacent to the Western Aranda area.

Although Strehlow's dictionary is being published for the first time now, it has had a major influence on the modern dictionaries produced in the last few decades, as well as on the unpublished dictionary (and other work) produced by his son T.G.H. Strehlow. Carl Strehlow's dictionary played an important role in the initial stages of the Arandic languages dictionaries program at the Institute for Aboriginal Development (IAD) in Alice Springs. It was the largest source used in developing a starter list for collecting information on words in different Arandic languages (together with work by Ken Hale, Gavan Breen and other researchers). The words in the starter list were used as prompts for speakers to provide information on their own language, and their information is what the modern dictionaries are based on. The series of major dictionaries published by IAD includes the Eastern and Central Arrernte to English Dictionary (Henderson and Dobson 1994), the Introductory Dictionary of Western Arrernte (Breen et al. 2000), the Central \& Eastern Anmatyerr to English Dictionary (Green 2010), the Kaytetye to English Dictionary (Turpin and Ross 2012) and the Alyawarr to English Dictionary (Green 1992; second edition by Blackman et al., forthcoming). In relation to Western Desert languages, the IAD program also produced the Pitjantjatjaral Yankunytjatjara Dictionary (Goddard 1996), and has contributed directly and indirectly to other works, including Glass and Hackett's (2003) Ngaanyatjarra \& Ngaatjatjarra to English Dictionary. The dictionaries program has also contributed in various ways to some of the Picture Dictionary volumes published by IAD Press.

2 See Chapter 6 in this volume for a detailed discussion of the differences between the various orthographies. 
With these major dictionaries published, and with smaller works and other research, it is now feasible to plan a combined dictionary of the Arandic languages, probably as a digital resource. Such a dictionary should include historical content, especially from Strehlow's dictionary but also from other early sources. Together with the entries from the various individual modern dictionaries, it would document the connectedness, difference and change within the Arandic languages. It would be a major ongoing resource for the Arandic communities and for Australian Indigenous studies more generally.

\section{The languages}

This is a comparative multilingual dictionary in that it includes Aranda, Luritja, German and some Dieri (now also written as Diyari). ${ }^{3}$ It is not an etymological dictionary: it does not attempt to relate the words of these Australian languages to each other as descendants of common ancestral languages. It also does not identify historical borrowings from one language to another, though it is reasonably clear that the neighbouring Aranda and Luritja languages have borrowed words from each other over a long period of time. A full analysis of this borrowing remains to be done, and no doubt this dictionary, along with others, will be key sources for that analysis.

Since Strehlow's spelling of Aranda and Luritja does not accurately and consistently represent the sounds of those languages, in this chapter his spelling of an Aranda word will generally be followed by its spelling in the two current orthographies for Western Aranda. The two alternative spellings are separated by a double-slash ' $/$ ', so for example tanalama \{tarnalhamal/ternelheme\} 'stretch yourself out'. The first alternative is in the Finke River Mission (FRM) orthography following the model in Roennfeldt et al.'s Western Arrarnta Picture Dictionary, and the second is in the IAD orthography following the model in Breen et al.'s (2000) Introductory Dictionary of Western Arrernte. For Strehlow's spelling of Luritja words, a modern spelling is provided following the model of Hansen and Hansen's (1992) Pintupi/Luritja Dictionary.

3 Interestingly, the names 'Luritja' and 'Aranda' - in any spelling - do not appear in Kempe (1891a), and in fact he gives no names for any varieties. However, the name of the Arandic language at Charlotte Waters was recorded in 1875 by Giles as 'Arrinda' (Taplin 1879). 
Strehlow's dictionary is in some ways basically two dictionaries: an Aranda to German dictionary, and an Aranda to Luritja dictionary. Aranda is clearly the primary language in this work overall. The most obvious evidence is that the list is alphabetically ordered-to the extent that it is-according to the Aranda words. Also, while almost 10 per cent of the 7,500-plus entries give an Aranda word with no equivalent in Luritja, there is only a handful of entries where a Luritja word is given without an equivalent in Aranda.

A multilingual dictionary like this may suggest to some readers that Aranda and Luritja are fundamentally equivalent in the meanings of words, that each word in one of these languages has a single corresponding word with the same meaning in the other language. This is generally not true of any two languages (though it might be true of very close dialects of the same language). It is not true of Aranda and Luritja. Certainly, there are many cases where there are corresponding words with the same meaning-or close to it—but there are many cases where there are not.

Firstly, there are cases where Strehlow gives the same Luritja word for two different Aranda words, for example:

\section{Aranda Luritja}

$\begin{array}{ll}\text { täkama alani } & \begin{array}{l}\text { ein Loch in einen hohlen Baum hauen } \\ \text { (mit dem Beil). \{chop a hole in a hollow tree } \\ \text { (with an axe), smash, break\} }\end{array} \\ \text { altjurilama alani } & \begin{array}{l}\text { ein Loch machen, öffnen (Tür) \{make a hole, } \\ \text { open (door) }\end{array}\end{array}$

In modern dictionaries, we see that Aranda altjurilama \{altjurelamal/altywerileme $\}$ and Luritja alani $\{$ alani $i\}$ both have at least two senses, (i) to make a hole or opening in something, and (ii) to open a door, hatch etc. However, Aranda täkama \{taakamal/takeme\} has a different meaning: 'smash in, break through, make something collapse (like a house) or cave in (like a burrow)' (Breen et al. 2000). Luritja alan $i$ and Aranda takamal/takeme can be both applicable to some particular situations, depending on the physical nature of the situation, but there are also other situations where alani is applicable but taakamall takeme is not. For example, alani is used to refer to the normal way of cutting open the belly of a kangaroo to gut it, but Aranda taakamall takeme is not. 
Conversely, in cases such as the following, there are multiple entries for the same Aranda word, with each entry apparently picking out the meaning in different contexts, and for each of these there is a different Luritja equivalent. In this particular case, the entries are consecutive, and it may be that Strehlow has specifically used separate entries to show the relationship between the Aranda and corresponding Luritja expressions.

Aranda Luritja

\begin{tabular}{lll} 
jurankama & $\begin{array}{l}\text { kurangañi } \\
\text { (Rausch, Wind) }\end{array}$ & $\begin{array}{l}\text { sausen (Wind), heulen (Sturm) } \\
\text { whistle (wind), howl (storm) }\end{array}$ \\
\hline jurankama & lulumanañi & $\begin{array}{l}\text { rauschen (Meer) } \\
\text { sough (sea) }\end{array}$
\end{tabular}

jurankama wilijiri wonkani fauchen (Schlange)

hiss (snake)

Finally, in many other cases, such as the following example, a number of Luritja words are given in the same entry. This should not be taken to mean that these words are necessarily all equivalent in Luritja.

\section{Aranda Luritja}

nilkna ngurtu, kanka, heimlich $\{$ secretly\}

mulata

On the basis of the modern dictionaries of related dialects, Aranda nilkna \{nyilkngal/nyelknge\} here is roughly 'secretly, stealing; theft' while the Luritja words would appear to have different meanings to each other, although related:

\section{Strehlow Current spelling}

ngurtu ngurrtiu

'selfishly, greedily, without sharing'

(Pitjantjatjara/Yankunytjatjara,

Goddard 1996)

4 This gloss may seem surprising since these languages are spoken so far from any ocean, but there is also laia \{laiya//laye\} 'sea', 'lake'. It is not clear what local phenomena this might have referred to, but very large bodies of water may have been known about second-hand through a chain of cultural contact between language groups. 


\begin{tabular}{|c|c|c|}
\hline mulata & mulyata & $\begin{array}{l}\text { 'illegally, without permission, against } \\
\text { a prohibition' (Ngaanyatjarra/ } \\
\text { Ngaatjatjarra, Glass and Hackett 2003) }\end{array}$ \\
\hline kanka & $k a a \underline{n} k a$ & $\begin{array}{l}\text { 'crow' and metaphorically, 'light- } \\
\text { fingered \{man/woman\}, someone } \\
\text { who hangs around suspiciously' } \\
\text { (Pitjantjatjara/Yankunytjatjara, } \\
\text { Goddard 1996) }\end{array}$ \\
\hline
\end{tabular}

\section{Dialects}

The Aranda words in the dictionary are said to be from the 'dialect of the Upper Finke area', and today the dictionary is often identified as the Western Aranda dialect, which is strongly associated with Ntaria (Hermannsburg) and neighbouring communities. However, the situation is more complex than this. Firstly, there are close to 300 words annotated by Strehlow as Northern (156 words), Southern (123) and Eastern varieties (8). Most of these are consistent with currently known dialect differences. In about a quarter of these instances, the entry also indicates what the corresponding Western Aranda form is. Secondly, there is evidence of words that are recognised today as other dialects, but are not annotated as such in the dictionary. For example, Strehlow's matja 'fire' does not occur in the modern Western Aranda dictionaries, but is found in the southern dialect Pertame (as metye). It may be that this type of situation reflects a more mixed population at Hermannsburg in Strehlow's time, with some speakers of dialects from other areas. Dialect divisions are not by nature clear-cut, so it may also be that in some cases the local dialects simply had more than one word with the same meaning - synonyms - and one or more of these synonyms just happened to be shared with another dialect, as so many words are. Finally, it is likely that there were originally smaller dialect distinctions - with perhaps just a few differences-within the 'Upper Finke area'.

The Western Desert language is both traditionally and currently spoken over an enormous area with many local dialects, shading from one into another. Strehlow identifies the Western Desert dialect in the dictionary as 'Loritja' for the first third of the notebook and as Kukatja for the remainder. Speakers of the dialect today usually label their language as Luritja. The naming of varieties of the Western Desert language is 
traditionally multilayered and somewhat variable depending on context and purpose, but it seems clear that Strehlow's Kukatja and Luritja both refer to basically the same variety. ${ }^{5}$ Strehlow reports that Kukatja was the name speakers used for themselves, and Luritja is the name originally used for them by Aranda speakers. In the dictionary, Strehlow identifies only a handful of words as belonging to other specific Western Desert dialects outside of the immediate area. All of these involve more southern or western dialects.

In some of the entries where more than one word is given for Luritja or Aranda, they are at least related in meaning, but may not all be from exactly the same dialect. For Western Desert dialects like Luritja, there is often a number of synonyms for a given meaning (Hansen 1984). The individual synonyms in a dialect are often also found in other dialects—but not necessarily all synonyms in every dialect. For example, in the following case Strehlow presents both Luritja itára and ngápiri as equivalent to Aranda para. Each of these words also occurs in other Western Desert dialects, but as Goddard (1996) shows, there are dialects where only one of these two occurs. Note also the small local differences in meaning in this example. ${ }^{6}$

\section{Aranda Luritja}

$\begin{array}{ll}\text { para itára, ngápiri } & \begin{array}{l}\text { Gummibaum (Eucalyptus rostrata) } \\ \text { \{gumtree }\end{array}\end{array}$

\section{Strehlow Current Dialect}

\begin{tabular}{llll}
\hline ngápiri & ngapini & $\begin{array}{l}\text { Pitjantjatjara } \\
\text { (not Yankunytjatjara) }\end{array}$ & $\begin{array}{l}\text { 'river red gum (Eucalyptus } \\
\text { camaldulensis)' }\end{array}$ \\
\hline itára & ițara & 'some areas only' & $\begin{array}{l}\text { 'river red gum (Eucalyptus } \\
\text { camaldulensis)' }\end{array}$ \\
& & $\begin{array}{l}\text { Pitjantjatjara \& } \\
\text { Yankunytjatjara }\end{array}$ & $\begin{array}{l}\text { opaca)' (Goddard 1996) } \\
\text { opood (Eucalyptus }\end{array}$
\end{tabular}

5 The term Kukatja is also used for a more remote variety of the Western Desert language spoken at Balgo in Western Australia and, traditionally, it appears to have been used to refer to other Western Desert varieties which distinctively use the word kuka for 'meat'.

6 The river red gum is now generally classified as Eucalyptus camaldulensis rather than Strehlow's Eucalyptus rostrata. The bloodwood was reclassified as Corymbia opaca in the 1990s. 
This is part of a complex pattern of synonyms in and across Western Desert dialects. Hansen (1984) describes each dialect as having many cases where there is a number of synonyms for a given meaning, though in the individual cases in a given dialect some synonyms are used more than others at a particular point in time. One factor is that if a particular synonym is placed under taboo following the death of a person with a similar-sounding name, other synonyms can be used instead. Speakers are also typically familiar with synonyms that they attribute to dialects other than their own.

\section{Entries, words and expressions}

One way to understand the basic organisation of information in a dictionary, and therefore to compare dictionaries, is to ask the question: What kind of list is this dictionary? In this section, we will try to answer this question for Strehlow's dictionary.

\section{Basic entry structure and ordering}

The basic structural considerations for a dictionary entry are (i) the basis for what constitutes a distinct entry, and (ii) what type and level of information is provided in each entry. There is of course a wide range of possibilities for a given dictionary depending on the information that is available to the compilers, the resources and time that is applied to the work, and the compiler's goals for the use of the dictionary. For example, on the first point here some dictionaries, such as Goddard's (1996) dictionary of Pitjantjatjara and Yankunytjatjara, have entries for individual grammatical suffixes, whereas others such as Hansen and Hansen's (1992) Pintupi/Luritja dictionary do not. In general, Strehlow does not have separate entries for suffixes, but he does annotate around 50 items as postpositions, a group which includes postpositional particles or clitics, and the odd suffix. 
In order to get a broad overview of the structure of entries in Strehlow's dictionary we can compare here a single entry, focusing on Luritja, with corresponding entries from a range of dictionaries ${ }^{7}$ of Western Desert language dialects that are closely related to Luritja. Note that nangañil nyanganyi and nyangu are different tense forms of the same verb.

Strehlow Dictionary (1901-09)

răma sehen nangañi $\{$ see, look, $\ldots\}$

Martutjarra Luritja (Cook 1982)

nyangu (wa) Vt see, look at

Pintupi/Luritja (Hansen and Hansen 1992)

nyangu (wa) v. looked; saw; the norm is for limited eye contact in conversations and addressing large gatherings; prolonged eye contact which is the European norm can be offensive, implying that you don't trust or recognise the person; prolonged eye contact with the opposite sex can be interpreted as a sexual advance; see ngurrtjunu, nyirrkingu, warinyangu, nyirrkinyirrkinpa, pinkurrwarranu, tjarangkanu, taarrnyinangu, pinkulutingu, yinawarranu, rupungu, miranu.

Pitjantjatjara/Yankunytjatjara (Goddard 1996)

nyanganyi transitive verb (ng)

1. see, watch, look at, notice: Ankulala nyakuku? Shall we go have a look? / Wanyuli arkara nyawa! Let's have a look! / Wampa. Ngayulu nyakunytja wiya. Search me. I haven't seen (him). I Ngayulu pulkara pukularipai mamangku kuka katinyangka nyakula. I used to be so happy when I saw (my) father bringing meat. / Tjitji tjuta pakuringkupai mungangka tipi nyakunytjatjanu. The kids get tired (during the day) after watching TV at night. / Wanyuli malaku ara nyakunytjikitja. Let's just go back and check. I Munul ankula ankula mitunu kalaya tjina, pulka alatjitu. Munul mawanara nyangu manngungka pupanyangka. After a while she came upon some emu tracks, really big ones. And she followed and saw (an emu) hunched over its nest.

7 Cook's (1982) entry is from a relatively short vocabulary within an undergraduate Honours thesis, rather than a stand-alone dictionary, but it does represent a useful comparison as a dictionary entry structure intermediate between Strehlow's and the more extensive modern dictionaries. 
2. find: Cassette panya nyuntu nyangu? Have you found your cassette player? I Kaya minyma tjutangku ankula ankula mina putu nyangu. The women went off but couldn't find (any) water.

3. (with purposive object ending -ku/-mpa) look for.

4. (of telegram, letter, etc.) get, receive: Telegram-na iyanu, paluru nyangu. Munu yaaltji-yaaltji mitingi pitjanytja wiya. I sent (him) a telegram, and he got it. So how come he didn't come (to) the meeting.

nyangu saw (past); nyangangi was watching, would see (past continuous); nyangama could see, keep watching (imperative continuous); nyakuku might see (future); nyakula having seen, on seeing (serial form); nyakunytja (nominal form); nyakupai used to see/watch (characteristic); nyawa look out! (imperative).

anganyanganyi look around to see whether it's safe, be on the lookout for danger (anga- 'block').

ngulu nyangama keep watch on, keep an eye on (ngulu 'wary'): Nyuntunku pika palatja uti ngulu nyangama. You should mind that injury of yours.

nyakula wanani follow (wan_an_i) with the eyes, watch something as it moves along.

nyakula wantinyi ignore, leave alone: Kuwarimpayal nyakulalta wantinyi palu nganana ngalkupai tjulpu tjuta. These days they (kids) leave them alone but we used to eat birds (when we were kids).

para-nyanganyi look around.

nyakukatinyi transitive verb $(\varnothing)$

1. look for while going along: Malu kutjupala nyakukatima. We should keep a look out for another kangaroo as we go along.

2. watch over an extended period of time.

nyakulinanyi transitive verb $(\mathrm{n})$

look for something while going along / Ma-pitjala nganan_a put_u nyakulinangi, mingkulpaku. As we went along we were looking around in vain for native tobacco.

In terms of the types of information, Strehlow's entry clearly has the simplest structure here, with a single Luritja word and a one-word German gloss, 'sehen' \{look, see, ...\}. Cook (1982) adds grammatical 
information on each verb's conjugation-identified by the label '(wa)' and its transitivity - 'Vt' to indicate a transitive verb. Strehlow explicitly indicates grammatical information such as transitivity only sporadically. It is clear though from his 1910 grammatical notes that he was well aware of the details of Aranda and Luritja grammar. Hansen and Hansen's (1992) entry further adds cultural information that is presented as relevant to this particular word, on eye contact in this case.

The Pintupi/Luritja entry also lists a range of cross-references to other words with related meanings in that dictionary. For example, the first cross-reference ngurrtjun $u$ is defined in its entry as 'examined, tested, inspected; to inspect articles with a view to choosing the best one; to look over an object carefully'. Such cross-references have two functions. Firstly, they indirectly add to the definition of nyangu by identifying the area(s) of meaning that the word falls in, and point to the aspects of meaning which these related words share with nyangu. Secondly, the cross-references indirectly point to the aspects of meaning which distinguish the words from each other. For the language learner, the cross-references can identify the choices to be made in selecting an appropriate word. This type of information can also come from the Finder section of the Pintupi/Luritja dictionary where the entries invite the user to consider what the most appropriate word might be, for example:

saw: rupungu, tjarangkanu, miranu, nyuulykunu, yinawarranu, nyangu.

Goddard (1996) does not provide any cross-references to related words in the particular Pitjantjatjara/Yankunytjatjara (P/Y) entry above, though this dictionary does indicate synonyms in many other entries. The semantic analysis is more sophisticated in distinguishing four specific senses within the range of meaning of the word, and the explication of the meanings of these senses is enriched by providing examples of use in different situations, and translations of these examples. The entry also provides additional grammatical information, a list of the different tense forms: 'nyangu saw (past); nyangangi...'. This is not routinely provided in verb entries in this dictionary because there is a regular pattern of such inflectional forms for each verb conjugation. Without explicitly stating so, the inflectional forms are listed in the nyanganyi entry because some of them are irregular (i.e. different from what would be expected for a standard NG-class verb). 
Another obvious aspect of the $\mathrm{P} / \mathrm{Y}$ dictionary is that it groups together as subentries in one complex entry a set of expressions that are based on nyanganyi. Strehlow's dictionary also provides such a set of expressions, but they are all independent entries. See the sample below (leaving out the Aranda equivalents). This set is more extensive than in the $\mathrm{P} / \mathrm{Y}$ dictionary nyanganyi entry, primarily because Strehlow is providing these Luritja expressions with the intent of matching each of the Aranda expressions he lists.

\begin{tabular}{|c|c|c|}
\hline sich umsehen & $\begin{array}{l}\text { nakulaenni } \\
\text { \{nyakulayini } i(?)\}^{8}\end{array}$ & $\begin{array}{l}\text { 'to look around } \\
\text { (refl.)' }\end{array}$ \\
\hline spähend stehen & $\begin{array}{l}\text { nakulakanjini } \\
\{\text { nyakula kanyini\} }\end{array}$ & 'stand looking' \\
\hline $\begin{array}{l}\text { übersehen, nicht } \\
\text { sehen }\end{array}$ & $\begin{array}{l}\text { nakula kanjini } \\
\text { \{nyakula kanyini\} }\end{array}$ & 'overlook, not see' \\
\hline $\begin{array}{l}\text { übersehen, nicht } \\
\text { sehen }\end{array}$ & $\begin{array}{l}\text { ninkiltunkulá nangañi } \\
\{<?>\text { nyanganyi\} }\end{array}$ & 'overlook, not see' \\
\hline $\begin{array}{l}\text { mit eigenen } \\
\text { Augen sehen }\end{array}$ & $\begin{array}{l}\text { kurunka nangañi } \\
\{\text { kurungka nyanganyi\} }\end{array}$ & 'see with own eyes' \\
\hline $\begin{array}{l}\text { mit dem Auge } \\
\text { zwinkern }\end{array}$ & $\begin{array}{l}\text { kuruterbaterbara nangañi } \\
\{\text { kuru-<?> nyanganyi\} }\end{array}$ & 'wink with the eye' \\
\hline $\begin{array}{l}\text { (Gott sehen), } \\
\text { träumen }\end{array}$ & $\begin{array}{l}\text { tukura nangañi } \\
\{\text { tjukurra nyanganyi\} }\end{array}$ & $\begin{array}{l}\text { '(see God), } \\
\text { to dream' }\end{array}$ \\
\hline sieh! Seht! & $\begin{array}{l}\text { nauai! } \\
\{\text { nyawayi!\} }\end{array}$ & 'see! Look!' \\
\hline $\begin{array}{l}\text { wiedersehen } \\
\text { (v. Freunden) }\end{array}$ & $\begin{array}{l}\text { ngaparku nangañi } \\
\text { \{ngaparrku nyanganyi\} } \\
\text { nakula pungañi } \\
\text { \{nyakula punganyi\} }\end{array}$ & 'see again (friends)' \\
\hline
\end{tabular}

8 The forms in modern Luritja spelling are the author's interpretation based on the form and meaning given by Strehlow and the available descriptions of neighbouring Western Desert dialects. Interpretation by knowledgeable speakers of Luritja may remove the uncertainties here. 


\begin{tabular}{|c|c|c|}
\hline $\begin{array}{l}\text { (viele) einander } \\
\text { sehen, wieder sehen }\end{array}$ & $\begin{array}{l}\text { nakunakulapungañi } \\
\text { \{nyakunyakula punganyi\} }\end{array}$ & 'see again' \\
\hline $\begin{array}{l}\text { (herankommen) } \\
\text { sehen }\end{array}$ & $\begin{array}{l}\text { ngalanangañi } \\
\text { \{ngalya-nyanganyi\} }\end{array}$ & 'see (approaching)' \\
\hline sehen & $\begin{array}{l}\text { nangañi } \\
\{\text { nyanganyi\} }\end{array}$ & 'see' \\
\hline $\begin{array}{l}\text { mit eigenen Augen } \\
\text { sehen }\end{array}$ & $\begin{array}{l}\text { kurultu nangañi } \\
\{\text { kurultu(?) nyanganyi }\}\end{array}$ & $\begin{array}{l}\text { 'see with one's own } \\
\text { eyes' }\end{array}$ \\
\hline zur Seite sehen & $\begin{array}{l}\text { talbanku nangañi } \\
\{\text { tjalpangku(?) nyanganyi\} }\end{array}$ & 'look to the side' \\
\hline schielen & $\begin{array}{l}\text { kuru niltunku nangañi } \\
\{\text { kuru ngiltungka(?) nyanganyi\} }\end{array}$ & 'be cross-eyed' \\
\hline übersehen & $\begin{array}{l}\text { ninkiltunkula nangañi } \\
\{<?>\text { nyanganyi }\}\end{array}$ & 'overlook' \\
\hline $\begin{array}{l}\text { bei der Rückkehr } \\
\text { sehen }\end{array}$ & $\begin{array}{l}\text { ngalanakulakulbañi } \\
\{\text { ngalya-nyakula kulpanyi\} }\end{array}$ & 'see on the return' \\
\hline (liegen) sehen & $\begin{array}{l}\text { manangañi } \\
\{m a-n y a n g a n y i\}\end{array}$ & 'see (lying)’ \\
\hline vor sich liegen sehen & $\begin{array}{l}\text { manakukatiñi } \\
\{\text { ma-nyakukatinyi\} }\end{array}$ & $\begin{array}{l}\text { 'see it lying in front } \\
\text { of oneself' }\end{array}$ \\
\hline $\begin{array}{l}\text { auf der Wanderung } \\
\text { erblicken }\end{array}$ & $\begin{array}{l}\text { nangañi jenkula } \\
\{\text { nyanganyi yankula\} }\end{array}$ & 'see on the walk' \\
\hline
\end{tabular}

These separate entries above are not all actually consecutive in Strehlow's dictionary.

Unlike the $\mathrm{P} / \mathrm{Y}$ dictionary, Strehlow's is not organised specifically so that separate but related Luritja expressions are grouped together, though this does result coincidentally in some cases. Mostly there is not even an indication of the relationship between expressions like the above (except for a few cross-references). Aranda related expressions are often grouped together simply because of the alphabetical ordering. This happens because of the particular facts of derived word forms in Aranda, and also 
in some cases because of the way Strehlow's spelling under-differentiates the sounds in words. There are a few cases, though, where Strehlow ignores alphabetical order in order to group related expressions together. These mostly involve multi-word expressions, as we can see in the set of consecutive entries below where none of the indented lines would be in that position if ordered strictly alphabetically. The indenting itself explicitly represents these as subentries of ankama \{ngkamal/ngkeme\}. The choice of which expressions are presented as subentries can be inconsistent: we can see more words below related to ngkamal/ngkeme that are distinct entries, with unrelated words occurring in between in some cases. There is no indenting in most such cases in the dictionary.

ankama

bailba ankama $\quad$... talk/speak unintelligible

barbuta ankama $\quad \ldots \quad$ talk/speak unintelligible

etatua ankama $\quad \ldots \quad$ talk for a very long time

erilkna ankama, $\quad \ldots \quad$ speak loud

entára ankama

ritjinja ankama $\quad$... speak softly

ankanankana $\quad . . \quad$ speaker

ankalabuma

ankaúerama

ankalelama

ankaratnapallanama

inkana

ankankalintama

inkanga

ankāra
... ask for, beg for, hum (beetle)

... discuss with (men)

... trs. produce sounds

... say in chorus, twit and sing in the choir

... all

... ascend singing (bird)

... armpit

... the juice (of caterpillars, of fruit), type of tree

We can also see another aspect of entry ordering here that relates to the handwritten nature of the original and its status as a draft. The words inkana and inkanga above, which are well out of alphabetical order, were originally written as ankana and ankanga respectively and then overwritten with the initial ' $i$ '. The correct forms also occur later in roughly their expected place in alphabetical ordering. 
Now that the dictionary has been transcribed into a digital form, there are clear opportunities here to re-present the information to both make expressions easier to find and to indicate the relationships between them. The Aranda expressions in the entries could be sorted into consistent alphabetical order, and a reversal could also list the Luritja expressions in alphabetical order. While this would improve usability for some purposes, we should be aware that each of Strehlow's entries was written in the context of its neighbouring entries, and the original ordering may therefore be necessary to help interpret an entry. In a digital version of the dictionary, normal searching would make it simpler to find words even when they are in quite distant entries. In a more sophisticated digital version, entries could be linked to explicitly show the relationships between them, and though this would be a fairly large task it would make it possible to present to the user a set of related expressions for comparison.

\section{Single and multi-word expressions}

In nearly 90 per cent of entries there is a single Aranda headword, as illustrated in the example of răma 'see' above. Most of the remainder have multi-word expressions, two or more synonyms, or in just a few cases an example sentence. There are various types of multi-word expressions, including classifier constructions such as manna inkua below where the classifier nominal manna \{marnal/merne\} PLANT FOOD combines with the nominal inkua to focus on this plant as a source of food.

$\begin{array}{lll}\text { inkua, manna inkua } & \text { Schilf, dessen Wurzeln } & \text { reed, its roots are } \\ \text { \{ingkwall ingkwe, } & \text { gegessen werden } & \text { eaten }\{\text { bulrush } \\ \text { marna ingkwall } & & \\ \text { merne ingkwe\} } & & \end{array}$

\begin{tabular}{lll}
\hline $\begin{array}{l}\text { untjala ngama } \\
\text { \{untjala kngamall }\end{array}$ & $\begin{array}{l}\text { auf der Schulter tragen } \\
\text { (kleine Kinder) }\end{array}$ & $\begin{array}{l}\text { carry on shoulder } \\
\text { (small children) }\end{array}$ \\
& &
\end{tabular}

The distinction between single headword and multi-word expressions is not always as straightforward as it might seem. To an extent, it is a matter of writing conventions whether some expressions are written as a single word or as two or more words. There may also be variation between the possibilities. This is a common situation in various languages, including English, where some compounds can be written in different 
ways, for example car park, car-park and carpark are all in common use. Similarly, among the Luritja forms above related to nyanganyi 'see, look, ...', Strehlow clearly gives a two-word version nakula kanjini and a oneword version nakulakanjini for the same expression (nyakula kanyini) in different places. In a handful of cases, Strehlow even presents a short sentence as a single word:

Strehlow's spelling: ngamilai!

Modern spelling:

$\begin{array}{ll}\text { ngaama } & \text { ilai } \\ \text { ng-ame } & \text { il- } \varnothing \text {-aye } \\ 2^{\text {nd PersonSingularSubject- }} & \text { say-Imperative- } \\ \text { Contrast } & \text { Emphasis }\end{array}$

Strehlow's translation: Du selbst sagen \{Say it yourself?\}

\section{Citation forms}

Dictionary entries are, of course, based on a headword or expression. The headword is typically a conventional citation form which actually represents a whole set of inflected words. For example, most English dictionaries do not have separate entries for walk, walks, walking and walked. They have a single entry which expresses the idea that while this is a set of distinct words in one sense, they also together constitute a single word in another sense. In the second sense here, the overall set of these words constitutes the lexeme WALK. The specific words walk, walks, walking and walked are the inflectional forms of the lexeme WALK. In a dictionary, one of the inflectional forms (e.g. walk) is typically selected as the citation form that represents the lexeme. Citation forms like this are typically chosen by some general principle in a dictionary, rather than on a case-by-case basis. The citation form of verbs in English can be described in grammatical terms as the base form (because it does not include a suffix: walk in contrast to walk-s, walk-ing and walk-ed), or as the infinitive form (which is the form that occurs when tense is not represented, especially in the infinitive construction with the preposition to, e.g. 'to walk' or to be). For English, the citation forms for nouns and verbs are a very well-established tradition going back at least as far as the early dictionaries of the sixteenth century. 
When there is no earlier tradition of dictionaries to follow in a language, the citation form is selected by lexicographers on the basis of factors such as whether speakers have a sense that one inflectional form is basic in each lexeme, or even on the basis of common translation practices in the community. It may also take into account the target audience and the ways they are expected to use the dictionary. Sometimes a citation form is chosen because the form itself indicates important grammatical information about the lexeme.

In both Aranda and Luritja, most vocabulary items have a number of distinct inflectional forms: nominals (nouns, adjectives etc.) have different case forms and verbs have different forms according to tense etc., as we see in the following tables (which show only some of the inflectional categories for each).

\begin{tabular}{|c|c|c|c|}
\hline & & Aranda & Luritja \\
\hline child (intransitive subject) & Nominative & katjial/ketyeye & pipirri(nya) \\
\hline child (transitive subject) & ERGATIVE & $\begin{array}{l}\text { katjialall } \\
\text { ketyeyele }\end{array}$ & pipirringku \\
\hline for a/the child & Purposive & $\begin{array}{l}\text { katjiakall } \\
\text { ketyeyeke }\end{array}$ & pipirriku \\
\hline to(wards) a/the child & Allative & $\begin{array}{l}\text { katjiurnall } \\
\text { ketyeyewerne }\end{array}$ & pipirrikutu \\
\hline from a/the child & Ablative & $\begin{array}{l}\text { katjiangall } \\
\text { ketyenge }\end{array}$ & pipirringuru \\
\hline$\cdots$ & $\cdots$ & $\cdots$ & $\cdots$ \\
\hline \multicolumn{4}{|c|}{$\begin{array}{l}\text { For nouns in both Aranda and Luritja, it is a typically a straightforward } \\
\text { matter of selecting the form without a suffix. In the above table, this is } \\
\text { the Nominative case form, and this is the inflectional form that Strehlow } \\
\text { chose. For verbs, the choice of a citation form is more complicated. For one } \\
\text { thing, in Luritja there is no regular base form which has no suffixes. } \\
\text { For example, in the case below, there is no word patja corresponding to } \\
\text { the English base form 'bite': every inflectional form of this Luritja lexeme } \\
\text { has one suffix or another. }\end{array}$} \\
\hline
\end{tabular}




\begin{tabular}{|c|c|c|c|}
\hline & & Aranda & Luritja \\
\hline bites, is biting & Present & $\begin{array}{l}\text { utnhumal/ } \\
\text { uthneme }\end{array}$ & patjani \\
\hline will bite & Future & $\begin{array}{l}\text { utnhitjanhall } \\
\text { utnhetyenhe }\end{array}$ & patjalku \\
\hline bite! (an order) & IMPERATIVE & utnha!//utnhe! & patjala! \\
\hline bit & PAST & $\begin{array}{l}\text { utnhukall } \\
\text { utnheke }\end{array}$ & patjanu \\
\hline
\end{tabular}

In order to assess Strehlow's choice of Present tense as the citation form for verbs, it is necessary to consider the grammatical structure of words in these languages.

\section{Grammatical information}

As the comparison with modern central Australian dictionaries above shows, a lexical description typically requires information on the grammar of individual words, both the internal composition of words and relationships between them, and the properties which determine how they form phrases and clauses together, such as transitivity. Strehlow provides explicit information of this kind only sporadically in the dictionary, but some clues can be found in the citation forms, the grouping of entries, and the definitions. In this section, we examine some key aspects of grammatical information relating primarily to verbs.

\section{Verb inflections and verb classes}

Strehlow and Arandic lexicographers since him follow Kempe (1891a) in selecting the Present tense form of the Aranda verb as the citation form, for example ngama 'carry' $\{$ kngamal/kngeme $\} .{ }^{9}$ Indeed present tense and similar verbal categories are commonly used as citation forms in

9 The earliest known published list of vocabulary in an Arandic language, Christopher Giles's 1875 vocabulary from Charlotte Waters in northern South Australia (published in Taplin 1879), also gives Aranda verbs in the Present form, but the corresponding English verbs are given in the -ing participle form, for example 'dying'. 
dictionaries of Australian languages. It is the citation form in the modern Western Arrarnta Picture Dictionary (Roennfeldt et al. 2006) and the Introductory Dictionary of Western Arrernte (Breen et al. 2000). Present tense seems to be a natural citation form for most verbs for Aranda speakers today. It is the form that is typically given in responses to researchers' and learners' questions such as 'How do you say eat?' or 'What's the word for fall?' However, the Aranda Present is not the only possible answer to such questions: occasionally older speakers especially may give the Aranda Imperative (order) form, presumably because they interpret the English base form as a request for a translation of the English Imperative, for example 'eat!'.

The Aranda Present citation forms are matched in Strehlow's German translations with the infinitive forms of German verbs, which is the standard citation form in German dictionaries. For example, Aranda răma $\{$ ramal/reme $\}$ and Luritja nangañi $\{$ nyanganyi\} are glossed as sehen (translated into English as 'see, look, ...'). Kempe's (1891a) wordlist gives the base/infinitive form of English verbs. Kempe's choice of the Aranda Present as the citation form in his dictionary may actually have been an attempt to match the English, and perhaps German, Infinitive forms. In a rather unclear statement in his grammatical description, he says that the Aranda Present form 'also represents the Infinitive of the verb, there being no other form to indicate it, so that the meaning is, "I do beat," or "I beat."' (1891: 14). Other Aranda forms also correspond to the English and German Infinitive forms in various functions. The distinct Aranda Imperative form would match the English base/infinitive form in its imperative function, for example 'Look!'. The Aranda Purposive form, for example ritjakal/ retyeke 'see-PURP', matches the English '(to) see' and German 'sehen' Infinitive forms in uses such as 'go to see ...'.

With just a couple of exceptions, Strehlow cites Luritja verbs in a similar way to the Aranda, that is, in the corresponding Present tense form, e.g. nangañi \{nyanganyi\} 'see, look, ...'. The recent Luritja Picture Dictionary (Hansen et al. 2011) also uses the Present as the citation form, but some other modern dictionaries of Western Desert dialects have chosen differently. Hansen's Pintupi/Luritja dictionary uses the Past Perfective form, as shown in the comparison of entries above: nyangu 'saw'. Glass and Hackett's (2003) Ngaanyatjarra \& Ngaatjatjarra to English Dictionary uses the Future form: nyaku 'will see'. The choice of the citation form in these cases does not necessarily determine the English citation form in definitions. For the Pintupi/Luritja dictionary's Past tense citation form, 
the definition is a direct translation, that is, with the Past tense form of the English verb, e.g. nyangu 'saw'. Cook's wordlist also has the Luritja Past tense as the citation form but gives the English base/infinitive form in the definition, e.g. nyangu 'see, look at'. Similarly, the Future tense citation form for Ngaanyatjarra/Ngaatjatjarra words is matched by the English base/infinitive citation form, e.g. nyaku'see, ...' rather than 'will see, ...'.

Unlike Aranda, in Luritja and other dialects of the Western Desert language there are four basic classes of verbs (also called conjugations). These classes are defined by the overall pattern of the inflectional forms of each verb in the different tenses etc., as demonstrated by an example verb from each class.

\begin{tabular}{|c|c|c|c|c|}
\hline Verb class label & $\varnothing$ & LA & WA & RRA \\
\hline \multirow[t]{2}{*}{ Alternative LABEL } & $\varnothing$ & $\mathrm{L}$ & NG & $\mathrm{N}$ \\
\hline & 'sit' & 'seek' & 'hit' & 'go’ \\
\hline Perfective Imperative $^{10}$ & nyina! & ngurrila! & puwa! & yarra! \\
\hline IMPERFECTIVE IMPERATIVE & nyinama! & ngurrinma! & pungama! & yanama! \\
\hline Present & nyinanyi & ngurrini $i$ & punganyi & yananyi \\
\hline Future & nyinaku & ngurrilku & pungkuku & yankuku \\
\hline Past Perfective & nyinangu & ngurrinu & pungu & yanu \\
\hline Past Imperfective & nyinangi & ngurriningi & pungangi & yanangi \\
\hline Participle & nyinarra & ngurrira & pungkula & yankula \\
\hline$\ldots$ & $\ldots$ & $\ldots$ & $\ldots$ & $\ldots$ \\
\hline
\end{tabular}

The verb classes are labelled here in the standard ways used for Western Desert dialects. The top set of labels are based on the form of the Perfective Imperative: LA class verbs mark the Perfective Imperative by adding the suffix -la to the verb stem, ngurri-above, and similarly with the suffixes $-w a$ and -rra respectively for WA and RRA class verbs, added to the stems

10 The meanings of the inflectional categories in this language do not precisely match the inflectional categories of English. But, as a rough indication: Perfective Imperative $\approx$ 'Do it!'; Imperfective Imperative $\approx$ 'Be doing it!'; Present $\approx$ 'is doing it'; Future $\approx$ 'will do it'; Past Perfective $\approx$ 'did it'; Past Imperfective $\approx$ 'was doing it'; Participle $\approx$ '(while/and) doing'. 
$p u$ - and $y a$-above. For $\varnothing$ class verbs, no suffix is added, which means that the word that consists of just the stem-with no suffix-has the specific Perfective Imperative meaning (rather than being a type of neutral form of the verb). The alternative verb class labels reflect the consonant, if any, that immediately precedes the $k u(k u)$ part of the Future forms, for example $\mathrm{L}$ class verbs have /l/, as in ngurri.l.ku above, and $\mathrm{N}$ class verbs have /n/, as in $y a . n . k u k u$ above. In $\varnothing$ class verbs no consonant occurs in this position, as in nyina.ku above.

As noted above, Strehlow did not indicate the verb class in a verb entry, though he was clearly aware of the different inflectional patterns illustrated in the preceding table. Given the inflectional patterns of the four conjugations, Strehlow's choice of the Luritja Present as the citation form does not provide enough information from the form itself to identify the verb class in all cases. The ending of the Present form ngurrini in the table above, for example, is sufficient to identify it as a LA class verb since no other verb class has the same ending ... $\underline{n} i$ for Present. Once the class of the verb is known, all the inflectional forms follow from that: ngurrilku 'will seek' etc. However, with the Present forms nyinanyi 'sit', punganyi 'hit', and yananyi 'go', their respective verb classes cannot be determined because the $\varnothing$, wA and RRA classes all end with ...nyi in the Present form. A reader would need to know that the composition of these verbs is nyina$n y i$, pu-nganyi and ya-nanyi respectively before they could identify the verb class of each. The only clues in the dictionary to the class of such verbs is that in a few cases the verbs also occur in a different inflectional form within another entry, as part of a larger expression or compound word, or in an example sentence. But the other entry has to provide enough information to recognise the verb. For example, in Strehlow's entry for nintini 'tell, teach, instruct, show', the example sentence contains the Perfective Imperative form yarra plus an emphatic ending -yi (his jerrai.) but the rather free translation he gives does not make this clear.

$\begin{array}{llll}\text { Strehlow's spelling: } & k a p i & \text { nintintaku } & \text { ngalajerrai! } \\ \text { Modern spelling: } & k a p i & \text { nintintjaku } & \text { ngalya-yarra-yi! } \\ \text { Analysis: } & \text { water:Object } & \text { show- } & \text { this.way-go- } \\ & & \text { Purposive } & \text { Emphasis }\end{array}$

Strehlow's translation: Zeig mir das Wasser. (Show me the water!)

Literal translation: Water to show (me) come! 
Unfortunately, Strehlow's spelling further reduces the limited ability to distinguish a verb as LA class ending in ... $\underline{n} i$ versus $\varnothing$, WA and RRA classes ending in ...nyi. He does not reliably represent the important distinction between an alveolar nasal $/ \mathrm{n} /$ (as also occurs in English), a retroflex /n/ and a laminal /ny/. So from just the spelling of his verb entry bakani, it is not strictly possible to know whether it is pronounced pakani or pakanyi, and it is therefore not possible to deduce which verb class his bakani is in, and therefore what the other inflectional forms of this verb are. There is a hint in the fact that when an /i/ vowel follows in the verb endings, he tends to represent $/ \mathrm{ny} /$ as $\langle\tilde{\mathrm{n}}>$ and $/ \underline{\mathrm{n}} /$ as $\langle\mathrm{n}>$, which would suggest that his bakani is probably pakani rather than pakanyi. But he does not represent these sounds consistently. The uncertainty in this case would be compounded because he also gives the verb as bakañi in some other entries such as wontira bakañi 'leave one behind', which suggests pakanyi instead of pakani $i$. A Luritja speaker of course knows the verb pakani $i$ 'rise, set off, ...' and can easily recognise this in Strehlow's spellings bakani and bakañi, but an accurate representation of the sounds is required for a description of the language.

If the goal of Strehlow's wordlist was just to allow Luritja speakers to find out the German or English equivalents of Luritja words they already know, then there would be no real need to indicate which class a particular verb is in or to list all the different forms of each verb in the dictionary. The speakers of the language already know what the forms of a given verb lexeme are (without even having to know that there are different verb classes). However, in a dictionary like Strehlow's, there are other users and uses. For an old verb that Luritja speakers today do not recognise, or for learners or researchers of Luritja, the requirement is an explicit description of the vocabulary of Luritja in which the class and/or inflectional forms of each verb should be indicated in some way. Most modern Western Desert dictionaries do this by explicitly indicating the appropriate verb class label in the entry, such as ' $\varnothing$ ', as we might do for an entry for wangkanyi 'speak, talk, ...'. This then tells us all the inflectional forms, for example the Past Perfective wangkangu 'spoke, talked, ...'. It is also possible to list all the different inflectional forms of a verb in an entry, but printed dictionaries tend not to do this for reasons of space, and perhaps readability of entries. As indicated in the discussion above of the $\mathrm{P} / \mathrm{Y}$ dictionary entry for nyanganyi, the inflectional forms are only listed because this is one of a handful of irregular verbs. Its inflectional forms do not completely follow the pattern of WA class verbs. For example, the Future form is nyaku, and not *nyangku which would be expected by the regular pattern. 


\section{Word formation}

The standard set of inflectional forms that each lexeme has in Aranda and Luritja can generally be analysed in terms of a specific suffix to represent each inflectional category. In the simplest cases, the inflectional suffix attaches to a single morpheme which constitutes the root of the word, for example, Luritja patjalku 'will bite' consists of the Future suffix -lku attached to the root morpheme patja-. The inflectional suffix may also attach to a combination of morphemes. These structures fall into two general types, derivation and compounding.

Arandic languages have complex verb structures, and for each basic verb there are usually distinct derived lexemes each with a specific variation of meaning. For example, Strehlow lists the following:

\begin{tabular}{|c|c|c|}
\hline CS $^{*}$ Aranda & Translation & Modern spelling \\
\hline mankama & grow & maangkamal/mangkeme \\
\hline mankerama & $\begin{array}{l}\text { grow up, grow again } \\
\text { (rising generation) }\end{array}$ & $\begin{array}{l}\text { maangkerramall } \\
\text { mangkirreme }\end{array}$ \\
\hline mankalelama & bring up (children) & $\begin{array}{l}\text { maangkalhelamall } \\
\text { mangkelhileme }\end{array}$ \\
\hline mankinja & $\begin{array}{l}\text { full-grown (trees), } \\
\text { grown up (humans) }\end{array}$ & $\begin{array}{l}\text { maangkintjall } \\
\text { mangkentye }\end{array}$ \\
\hline mankitjintjama & grow up & $\begin{array}{l}\text { maangkatjintyamall } \\
\text { mangketyintyeme }\end{array}$ \\
\hline mankalelarama & help to grow big & $\begin{array}{l}\text { maangkalhelarramall } \\
\text { mangkelhilerreme }\end{array}$ \\
\hline mankarankarerama & $\begin{array}{l}\text { increase, grow on } \\
\text { (clouds) }\end{array}$ & $\begin{array}{l}\text { maangkarraangkarrerramal/ } \\
\text { mangkerrangkerrirreme }\end{array}$ \\
\hline mankalankala & $\begin{array}{l}\text { grown up, fledged } \\
\text { (birds) }\end{array}$ & $\begin{array}{l}\text { maangkalhaangkalhall } \\
\text { mangkelhangkelhe }\end{array}$ \\
\hline
\end{tabular}

${ }^{*}$ Carl Strehlow

These are not random variations on the basic verb: they all consist of a number of individual distinct parts which each contribute their own meaning to the overall word. The verb root is followed by one or more 
derivational formatives, and then an inflectional suffix which provides the information about tense and related meanings. For example, in the following words, maangk-//mangk- 'grow' is the verb root and the final inflection is the Present tense suffix. The derivational element -alhel//-elhil- contributes a distinct causal meaning, hence 'cause to grow'.

\begin{tabular}{lll} 
maangk-amall & maangk-alhel-amall & maangk-atjintj-amall \\
\hline mangk-eme & mangk-elhil-eme & mangk-ety+inty-eme \\
grow-PRESENT & grow-CAUSE-PRESENT & $\begin{array}{l}\text { grow-DoUPWARDS- } \\
\text { PrESENT }\end{array}$ \\
& & CS: 'grow up' \\
& $\begin{array}{l}\text { literally: cause to grow } \\
\text { CS: 'bring up (children) }\end{array}$ &
\end{tabular}

Derivational formatives like Causative -alhel-//-elhil-play a very important role in expressing meaning in Aranda-they build a large proportion of the lexemes in the language (just as English derivation builds a large number of lexemes in English, and similarly for many other languages). Strehlow's dictionary entries do not identify the specific derivational formative or its individual meaning; however, it can often be inferred from the related words in the dictionary, especially if the particular derivational formative leaves the words together in the alphabetical ordering. Further, the meanings he gives for a derived lexeme do not always directly reflect the meaning of the root. For example, the gloss 'bring up (children)' might not automatically suggest a derivational relationship with a distinct lexeme that means 'grow up' (although in this case the relationship would be more obvious if the meaning was expressed with the local Aboriginal English expression 'to grow someone up'). In general, where Strehlow's definitions do not transparently relate derived and basic forms, there are a couple of reasons. In some cases, he is giving just one use of the derived word in a particular context. Even if this is a common use, there are often other uses of the word. A more developed dictionary of the language will need to not only identify different uses of a derived word but also identify the meaning of the specific derivational element that underlies those different uses. Secondly, in some cases, the meaning of the derived word may subtly go beyond what would be expected from the general meaning of the derivational element. 
A full discussion of the different derivational formatives belongs in a grammatical description, but we can at least see the significance here of the different derivational formatives in Aranda by surveying some of the more common ones.

In grammatical terms, the Causative formative -alhel-//elhil- above derives a transitive verb stem from certain intransitive verb stems, as in the following examples. The most common result is, as in the preceding case, to cause someone or something to do the action of the intransitive verb stem. Thus, 'to drop something' is expressed as 'to cause something to fall'. This element also derives transitive verbs from certain nominals (nouns, adjectives etc.), such as gata $\{k a t h a / / k e t h e\}$ below.

\begin{tabular}{|c|c|c|c|}
\hline $\begin{array}{l}\text { ankama }^{11} \\
\text { \{angkamall } \\
\text { angkeme\} }\end{array}$ & $\begin{array}{l}\text { say, speak, talk, } \\
\text { bleat (sheep), } \\
\text { crow (birds), } \\
\text { rustle (trees) }\end{array}$ & $\begin{array}{l}\text { ankalelama } \\
\text { \{angkalhelamall } \\
\text { angkelhileme\} }\end{array}$ & $\begin{array}{l}\text { (transitive) produce } \\
\text { sounds \{i.e. cause } \\
\text { something to make } \\
\text { a sound\} }\end{array}$ \\
\hline $\begin{array}{l}\text { itnima } \\
\{\text { tnyimal/ } \\
\text { tnyeme }\end{array}$ & fall & $\begin{array}{l}\text { itnilelama } \\
\text { \{tnyilhelamal/ } \\
\text { tnyelhileme }\end{array}$ & $\begin{array}{l}\text { fell, make fall } \\
\{\text { to drop something }\}\end{array}$ \\
\hline $\begin{array}{l}\text { gata } \\
\text { \{kathall } \\
\text { kethe\} }\end{array}$ & $\begin{array}{l}\text { place, spot, locality, } \\
\text { position, end; } \\
\text { outside, visible, } \\
\text { flat, public; light } \\
\text { \{exposed }\end{array}$ & $\begin{array}{l}\text { gatalelama } \\
\text { \{kathalhelamall } \\
\text { kethelhileme }\end{array}$ & $\begin{array}{l}\text { (transitive) uncover } \\
\{\text { expose }\}\end{array}$ \\
\hline
\end{tabular}

There are also a number of other formatives which derive a transitive verb stem. The -el-//-il- formative is related to alhel-//elhil-, and also derives transitive verbs from certain nominals, either as an alternative to alhel-//elhil-, or in addition to it.

\begin{tabular}{|c|c|c|}
\hline $\begin{array}{l}\text { antaka } \\
\{\text { antakall } \\
\text { anteke\} }\end{array}$ & wide, broad & $\begin{array}{l}\text { antakilama } \\
\text { \{antakelamall } \\
\text { antekileme\} }\end{array}$ \\
\hline
\end{tabular}

\footnotetext{
11 The modern Western Arrarnta pronunciation of these two words is without the initial /a/, and accordingly the standard modern spellings are ngkamal/ngkeme and ngkalhelamal/ngkelhileme. Initial $<\mathrm{a}>$ is used here in the modern orthographic forms of ankama and ankalelama to represent the sounds that Strehlow appears to have identified in these words at that earlier time. See Chapter 6 for further discussion of initial $<\mathrm{a}>$.
} 


\begin{tabular}{llll}
$\begin{array}{l}\text { altjura } \\
\text { \{altjurall } \\
\text { altywere\} }\end{array}$ & $\begin{array}{l}\text { hole (in ground, in } \\
\text { opood, in clothes); }\end{array}$ & $\begin{array}{l}\text { altjurilama } \\
\text { altjurelamall } \\
\text { altywerileme\} }\end{array}$ & $\begin{array}{l}\text { make a hole, open } \\
\text { (a door) }\end{array}$ \\
\hline $\begin{array}{l}\text { botta } \\
\text { purtall } \\
\text { purte\} }\end{array}$ & $\begin{array}{l}\text { lump, ball, tuft } \\
\text { of grass }\end{array}$ & $\begin{array}{l}\text { bottilama } \\
\text { purtelamall } \\
\text { purtileme }\end{array}$ & make (something) \\
& & into ball
\end{tabular}

The Inchoative formative, -err//-irr in the examples below, derives an intransitive verb stem from a nominal (noun/adjective), often with a meaning 'to become a certain way', although that may not always be transparent in English translations:

\begin{tabular}{|c|c|c|c|}
\hline $\begin{array}{l}\text { borka } \\
\{\text { purrkall } \\
\text { purrke\} }\end{array}$ & $\begin{array}{l}\text { tired, exhausted, } \\
\text { stiff }\end{array}$ & $\begin{array}{l}\text { borkerama } \\
\text { \{purrkerramall } \\
\text { purrkirreme }\end{array}$ & $\begin{array}{l}\text { become tired, } \\
\text { stiffen }\end{array}$ \\
\hline $\begin{array}{l}\text { karra } \\
\{\text { kaarrel/ } \\
\text { karre }\}\end{array}$ & awake & $\begin{array}{l}\text { karrerama } \\
\{\text { kaarrerramall } \\
\text { karrirreme }\end{array}$ & wake up \\
\hline $\begin{array}{l}\text { altjura } \\
\text { \{altjural/ } \\
\text { altywere }\end{array}$ & $\begin{array}{l}\text { hole (in ground, in } \\
\text { wood, in clothes); } \\
\text { open }\end{array}$ & $\begin{array}{l}\text { altjurerama } \\
\{\text { altjurerramal/ } \\
\text { altywerirreme }\end{array}$ & $\begin{array}{l}\{\text { (something) } \\
\text { opens (up)\} }\end{array}$ \\
\hline
\end{tabular}

The Reflexive formative, -lh//-elh in the examples below, derives an intransitive verb stem from a transitive verb stem. The most common meaning is 'do the action of the intransitive verb stem to oneself'. In other cases, it has the effect of de-emphasising either the actor or the affected object, which both serve to focus on the action itself.

\begin{tabular}{|c|c|c|c|}
\hline $\begin{array}{l}\text { ilknama } \\
\text { \{ilkngamall } \\
\text { irlkngeme\} }\end{array}$ & $\begin{array}{l}\text { (transitive) wash } \\
\text { \{something\}, clean } \\
\text { \{something\} (stroke) }\end{array}$ & $\begin{array}{l}\text { ilknalama } \\
\text { \{ilkngilhimal/ } \\
\text { irlkngelheme\} }\end{array}$ & $\begin{array}{l}\text { (reflexive) wash } \\
\text { \{yourself\} }\end{array}$ \\
\hline $\begin{array}{l}\text { banama } \\
\text { \{parnamall } \\
\text { perneme }\end{array}$ & $\begin{array}{l}\text { (transitive) paint on, } \\
\text { rub in, build (house); } \\
\text { decorate \{i.e. put } \\
\text { paint, ointment etc. on } \\
\text { something\} }\end{array}$ & $\begin{array}{l}\text { banalama } \\
\text { \{parnalhamall } \\
\text { pernelheme\} }\end{array}$ & $\begin{array}{l}\text { (reflexive) paint } \\
\text { on, rub on } \\
\text { \{i.e. put paint, } \\
\text { ointment etc. } \\
\text { on yourself }\}\end{array}$ \\
\hline
\end{tabular}




\begin{tabular}{|c|c|c|c|}
\hline $\begin{array}{l}\text { ilama } \\
\{\text { ilamal/ } \\
\text { ileme }\end{array}$ & $\begin{array}{l}\text { say \{something\}, tell } \\
\text { about something\} }\end{array}$ & $\begin{array}{l}\text { ilalama } \\
\{\text { ilalhamall } \\
\text { ilelheme }\end{array}$ & $\begin{array}{l}\text { announce } \\
\text { (a decision) } \\
\text { \{more generally: } \\
\text { say something } \\
\text { about yourself }\end{array}$ \\
\hline $\begin{array}{l}\text { liima } \\
\{\text { lyimall } \\
\text { lyeme }\end{array}$ & $\begin{array}{l}\text { mumble (magic words, } \\
\text { spells) \{sing an object } \\
\text { to enact its mystical } \\
\text { properties\} }\end{array}$ & $\begin{array}{l}\text { ljélama } \\
\text { \{lyilhamall } \\
\text { lyelheme\} }\end{array}$ & $\begin{array}{l}\text { sing \{i.e. focusing } \\
\text { on the action } \\
\text { rather than on } \\
\text { an object\} }\end{array}$ \\
\hline
\end{tabular}

The Reciprocal, -rr/l-err in the examples below, also derives an intransitive verb stem from a transitive one, but in this case, the meaning is 'do the action of the intransitive verb stem to each other'.

\begin{tabular}{|c|c|c|c|}
\hline $\begin{array}{l}\text { erkuma } \\
\text { \{irrkumal/ } \\
\text { irrkweme }\end{array}$ & $\begin{array}{l}\text { catch, seize, capture, } \\
\text { hold tight }\end{array}$ & $\begin{array}{l}\text { erkurama } \\
\text { irrkurramall } \\
\text { irrkwerreme }\end{array}$ & $\begin{array}{l}\text { embrace } \\
\text { \{i.e. hold each } \\
\text { other }\end{array}$ \\
\hline $\begin{array}{l}\text { tuma } \\
\{\text { tumall } \\
\text { tweme }\}\end{array}$ & $\begin{array}{l}\text { strike \{something\}, } \\
\text { kill }\end{array}$ & $\begin{array}{l}\text { turuma } \\
\{\text { turramal/ } \\
\text { twerreme }\end{array}$ & $\begin{array}{l}\text { fight }\{\text { each other }, \\
\text { battle }\end{array}$ \\
\hline
\end{tabular}

A number of nominalising formatives derive a nominal from a verb stem, for example:

\begin{tabular}{|c|c|c|c|}
\hline $\begin{array}{l}\text { ljélama } \\
\text { \{lyilhamal/ } \\
\text { lyelheme }\end{array}$ & $\begin{array}{l}\text { sing }\{\text { i.e. focusing on } \\
\text { the action rather than } \\
\text { on an object\} }\end{array}$ & $\begin{array}{l}\text { lielinja } \\
\text { \{lyilhinjal// } \\
\text { lyelhentye\} }\end{array}$ & $\begin{array}{l}\{a\} \text { song for } \\
\text { act of singing }\end{array}$ \\
\hline $\begin{array}{l}\text { ankama } \\
\text { \{ngkamall } \\
\text { ngkeme }\end{array}$ & $\begin{array}{l}\text { say, speak, talk, bleat } \\
\text { (sheep), crow (birds), } \\
\text { rustle (trees) }\end{array}$ & $\begin{array}{l}\text { ankanankana } \\
\text { \{ngkanhangkanhall } \\
\text { ngkenhengkenhe\} }\end{array}$ & $\begin{array}{l}\text { speaker } \\
\text { \{i.e. one who } \\
\text { speaks\} }\end{array}$ \\
\hline
\end{tabular}

The example of ngkanhangkanhal/ngkenhengkenhe also illustrates one of the many types of derivation in Aranda which involve reduplication: the suffix -anhl/-enh is attached to the root morpheme $n g k$-, and the whole resulting unit is then doubled. 
There is a wide range of formatives which add information about motion that is associated with the verb action. The particular type in the following examples all involve compounding with a motion verb, here lhamal/ lheme 'go', and alpumall alpeme 'return'.

\begin{tabular}{|c|c|c|c|}
\hline $\begin{array}{l}\text { imbuma } \\
\text { \{impumall } \\
\text { impeme }\end{array}$ & $\begin{array}{l}\text { let, let be, pass by } \\
\{\text { leave (alone)...\} }\end{array}$ & $\begin{array}{l}\text { imbalalama }{ }^{12} \\
\text { \{imparlalhamal/ } \\
\text { imperlalheme\} }\end{array}$ & $\begin{array}{l}\text { leave behind, } \\
\text { abandon }\{\text { i.e. leave } \\
\text { behind and go }\}\end{array}$ \\
\hline $\begin{array}{l}\text { indama } \\
\text { \{intamal/ } \\
\text { inteme }\}\end{array}$ & lie ... & $\begin{array}{l}\text { inditjalbuma } \\
\text { \{intitjalpumall } \\
\text { intetyalpeme }\end{array}$ & $\begin{array}{l}\text { lie down on return } \\
\{\text { i.e. return and } \\
\text { then lie (down)\} }\end{array}$ \\
\hline $\begin{array}{l}\text { inama } \\
\{\text { inamal/ } \\
\text { ineme }\end{array}$ & $\begin{array}{l}\text { take, fetch, gather, } \\
\text { catch }\end{array}$ & $\begin{array}{l}\text { inilalbuma } \\
\text { \{inarlalpumal/ } \\
\text { inerlalpeme }\end{array}$ & $\begin{array}{l}\text { take with you } \\
\text { (when returning } \\
\text { home) \{take and } \\
\text { return\} }\end{array}$ \\
\hline
\end{tabular}

Finally, the various types of derivation shown above are not mutually exclusive, in that a single verb may contain more than one derivational formative. This sometimes results in quite complex verbs.

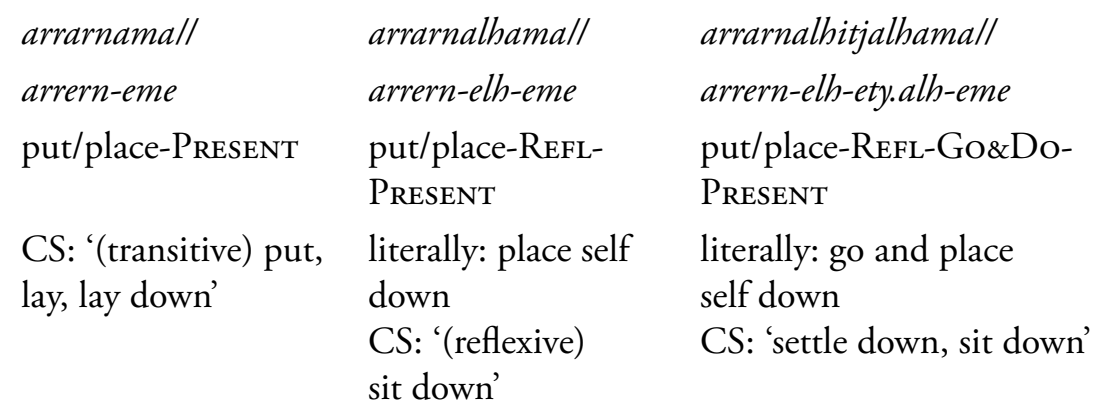

The list of derivational types above is far from exhaustive, but illustrates their enormous role in expressing meaning. In a general sense, the different types of derivation can apply to any basic lexeme, potentially creating a large set of derived lexemes for each basic one. In practice though, only some of the potential lexemes appear to be used with any frequency, and

12 There are actually three distinct entries for this word in different places in the dictionary, each with a slightly different gloss. 
this makes it all the more valuable that Strehlow was able to draw on his extensive collection of texts and on everyday speech to identify which derived lexemes occurred in the Aranda of that time.

For a few of the derived lexemes, Strehlow presents an analysis of the word structure in the dictionary. The more common patterns of word structure are described in his separate grammatical descriptions, and in Kempe (1891a). There is, however, a need for further grammatical analysis, in that some words appear to involve word structures that have not yet been described. Many of these cases will require quite careful analysis, and interpretation by speakers, especially where Strehlow's spelling does not clearly represent the actual sounds. For example, Strehlow's ankankalintama suggests at least two analyses. The most plausible analysis, shown in the gloss below, interprets his spelling 'int' as the Southern Arrernte (Pertame) verb root irnt- 'climb, go up, ...'.

\section{ankankalintama}

\{angk-angk-erl.irnt-eme\}

speak/sing-Reduplicated-Do.Rising-PRESENT

CS: 'singend aufsteigen (Vogel)' \{ascend singing (bird)\}

Alternatively, his 'int' may represent the verb root int- 'lie', even though its meaning does not appear consistent with the overall meaning of the word above. Such a compound construction is not known in the modern language; however, there is a parallel in the Alyawarr dialect where the corresponding root aynt- 'lie' occurs in a compound construction indicating action in an upwards direction. Of course, it may also be that 'int' in this word represents a completely distinct element. Further analysis of the many complex verbs in the dictionary may assist.

\section{Meaning}

Strehlow's sensitivity to meaning can be related to his broader focus on describing Aranda culture and documenting traditional texts, as well as the breadth of his knowledge of the language, and the demanding intellectual work of translating Christian materials into Aranda. Words are notoriously difficult to define with any precision, and perhaps more so for definition in a cross-language dictionary. His definitions appear to generally have a relatively high degree of accuracy, especially when 
compared to other works of his time. It should be remembered that his definitions are in German, and that the English glosses in the dictionary in this volume are a result of translation from Aranda by the speakers who have contributed to this publication project together with the compiler's translation from the German.

The comparison above of Strehlow's nangañi 'see' entry with the corresponding entry in some more recent dictionaries illustrates the general point that in a cross-language dictionary the meanings can be expressed in varying detail. Strehlow's German translations are generally relatively compact, although there are some entries where it is extensive. We can observe a number of different patterns of definition, starting from the simple cases where the Aranda or Luritja is translated by a single German word or expression, presumably because there is a close enough matchat least in Strehlow's understanding.

$\begin{array}{lll}\text { lěltja } & \text { Feind } & \text { enemy } \\ \text { \{liltye } & & \end{array}$

$\begin{array}{lll}\text { treranáma } & \text { furchtsam aus dem } & \text { get out of the way } \\ \text { trerranhamall } & \text { Wege gehen } & \text { frightened } \\ \text { terirrenheme } & & \end{array}$

In some cases, he has a range of German expressions which possibly only differ in style or register, for example:

kekatalama tadeln, Vorwürfe machen reprove, reproach

\{kikartalhamall

kikertelheme\}

ekaltilama stärken, befestigen strengthen, fortify
\{ekarltelamall
ikerltileme $\}$

In other cases, he lists a range of expressions with quite different meanings in German but which together sketch out the meaning of the Aranda or Luritja expression. He also often includes information on situations which the expression can refer to, often indicating aspects of the context in brackets. This definitional strategy essentially triangulates the underlying 
meaning without explicitly stating it as a single expression. While this may not always be optimal for language description, it provides a language learner with some fairly concrete situations for use.

rurkuma $^{13}$ Klappern, poltern, knarren, Rattle, rumble, creak, \{rwerrkeme, knirren, plätschern splash, patter (rain), rurrkeme\} (Regen), das mit den Füßen noise produced by the hervorgebrachte Geräusch, feet \{walking\}, crunch knirschen (Klappernd (Clattering down (stone)) herabfallen (Stein))

Sometimes Strehlow makes attempts to characterise an underlying meaning that cannot be expressed in German with a single word, and often without providing contextual instances that might assist a learner. For example, the following entry might be enhanced by relating this to the behaviour of kangaroos - as did one of the Aranda speakers involved in the project to bring this dictionary to publication.

tnanopanama (\{compound of\} tnama + nopanama) continually stop and stand for a while after going some distance; after one has been going along, stop, then go on, then stop, etc., continually after one has \{gone some distance $\{\ldots\}$, stop and stand for while, stop and stand again and again.

This is a case where the quality of Strehlow's definition helps to clarify how the verb is pronounced. He offers an analysis of this word as a compound consisting of a form of itnaamal/irtname 'stand' and napanamal/nepaneme which he glosses as 'always be, have, belong, stay, remain seated'. However, from its meaning and spelling, tnanopanama suggests that it might be the equivalent of Eastern/Central tnenhepenheme, roughly 'to repeatedly stop and stand while going along'. If this is so, Strehlow's analysis of this word suggests that he was unable to distinguish the $/ \mathrm{n} / \mathrm{and} / \mathrm{nh} /$ sounds of Aranda.

The remainder of this section considers some of the issues of definition, and how Strehlow has handled them. Compare Strehlow's translation of kekatalama above with Breen's below which has a different definitional strategy: a statement of the underlying meaning plus example contexts where the word might apply.

13 There are two separate entries for this verb in Strehlow's dictionary with slightly different definitions. 


\section{kikertelheme, kiketelheme}

not liking what someone does to you: for example, talking about you or criticising you. (Breen et al. 2000: 26)

Strehlow's definition would seem to involve expressing to someone that they have acted wrongly or badly, though perhaps not necessarily behaving badly to the person expressing that view. Breen's definition is focused on an individual's mental state. A corresponding expression to kikertelheme in Eastern/Central Arrernte is described as 'not wanting to talk to people or being unco-operative because you didn't get what you want; sulking, in a huff (Henderson and Dobson 1994: 67). These three attempts at definitions clearly have something in common, and if there is in fact a single underlying meaning across these dialects and times, then it still remains to develop an accurate definition. A proper evaluation of Strehlow's definitions will only be possible when such fine-grained work is completed. The case of kekatalama also demonstrates a general point that part of the continuing value of Strehlow's definitions is that they challenge lexicographers of Aranda and Luritja to refine their understanding of the underlying meanings of an expression.

In relation to botanical and zoological terms, Strehlow sometimes provides scientific names as well as general or local common terms, and in some cases-particularly birds-fairly detailed descriptions, as in the following example. In such cases, and where cultural detail is provided, he is going beyond a narrow model of a dictionary in the direction of an encyclopedia.

nturuta

\{nturrurtal/

nturrerte\}
Pigeon, brown with bonnet, rock pigeon, (Lophophaps leucogaster).--Red-brown wings with black stripes, black beak, grey-blue $\{\ldots$..? , red around the eyes, redbrown bonnet, white stripe from under the beak to under the eye, below this stripe a black ring which reaches up to the eye. White belly mixed with brown, growing darker towards the tail. Back brown with black bars. The long wing feathers brown with black tip, the internal wing feathers violet black.

As some of the examples above illustrate, Strehlow and other lexicographers face a range of issues because the range of meaning of a word in one language is not exactly the same as the range of meaning of the nearest word in another language. One way to appreciate the task is to examine 
categories of words which typically have relatively clear-cut systematic components of meaning. Such categories include pronouns and kin terms. The following is a relatively complex example drawn from the Aranda pronoun system. Strehlow glosses the Aranda second person pronoun rankara \{rraangkarral/rrangkerre\} and Luritja nurungari \{nyurrungarri\} as German $i h r$, but in fact $i h r$ only overlaps to a limited degree with rankara and nurungari. Firstly, German ihr refers to two or more people whereas rankara and nurungari refer specifically to three or more people. Put differently, German ihr can refer to two people, roughly 'you two', but rankara and nurungari do not. Aranda and Luritja both have separate pronouns for 'you two', mpaalal/ mpale and nyupali respectively.

Secondly, German ihr has a number of different grammatical functions. $\mathrm{Ihr}$ does match rankara and nurungari in one particular function of that word: second person plural nominative-roughly parallel to English plural 'you' in subject contexts like 'you sat down'. However, ihr has other functions that do not match rankara or nurungari at all: third person singular feminine possessive (parallel to 'her (food)'), third person singular feminine dative (parallel to '(wave) to her'), third person plural possessive (parallel to 'their (food)'), and the formal second person possessive both singular and plural.

Thirdly, in general, Aranda has different forms of each non-singular pronoun according to the kin category of the people referred to. These distinctions in pronouns are falling out of use in much of the Arandic area. They are probably no longer used in Western Aranda but they were recorded from elderly Western Aranda speakers in the 1990s (Breen 1998). They were therefore presumably known in Strehlow's time, though only a few of these pronouns are in the dictionary. The first form, rraakarriyangal/ rrakerreyenge, means 'you who are all in the same patrimoiety but in the opposite generation moiety'. This can refer, for example, to a father and his children but not to a mother and her children, or to a group of siblings. The second form, rraantharriyangal/ rrantherreyenge, means 'you who are not all in the same patrimoiety'. This can refer, for example, to a mother and her children, but not to a father and his children, or to a group of siblings. The third form, rraangkarral/rrangkerre, is Strehlow's rankara. It means 'you who are in the same patrimoiety and the same generation moiety'. It can refer, for example, to a group of siblings, but not to a father and his children, or to a mother and her children. In some other dialects where these kin-based pronouns are still in use, the pronoun in this last category is also used when kin distinctions are not 
being made, and so can be considered generic in terms of kin. Assuming that Aranda rankara also had such a generic meaning in Strehlow's time, his gloss is not incorrect in relation to kin categories; it simply does not include the kin-based meaning that the pronoun also has.

Finally, in some dialects of Aranda the second person plural can also be used as a singular pronoun in an indirect way to address just one person if they are in a specific respected kin category (Wilkins 1989: 46). This also needs to be included in an account of the meaning of this pronoun.

Strehlow was clearly sensitive to the quite different system of kin terminology in Aranda, and able to investigate the meaning of each kin term to some depth. We see this in the following example, in his definition strategy of listing the (German) expressions for all the relationships that are subsumed under Western Aranda tjia.

itia (Southern younger brother, younger sister, father's younger dialect), tjia brother's son, mother's younger sister's son, woman's \{irteye $(S), \quad$ younger sister's husband, man's younger sister's tjiyal/tyeye\} husband, father's younger brother's daughter, mother's younger sister's daughter, woman's younger brother's wife, man's younger brother's wife.

The definition given for this word by Breen et al. (2000) is simply 'younger brother or sister'. At first sight, this seems very incomplete by comparison, but it may capture the fact that all the relationships listed by Strehlow actually involve only the Aranda concepts of BROTHER or SISTER and, in the kin sense, younger. So while Strehlow's definition suits a technical description or a practical work for learners of Aranda, Breen's definition may better suit users who are familiar with the kin concepts of Aranda and perhaps other Aboriginal languages.

Meanings also reflect the introduced culture in a few cases. The missionary role of Strehlow and his colleagues in seeking terms to express Christian concepts and texts was a major project of translation (see Moore 2015). For example, a central concept in Aranda cosmology is altjirrallaltyerre, a complex term that might be glossed as the creation and continuing underlying fabric of the world. It is sometimes translated as 'the Dreaming' in some contexts today but it has been the established translation of 'God' in Lutheran practice since Kempe. (See Green 2012 for a discussion of the 
meaning and translations of this term.) As an entry on its own, Strehlow gives only the Christian meaning for Altjira, but recognises its original meaning where it occurs within other expressions: ${ }^{14}$

\begin{tabular}{lll}
$\begin{array}{l}\text { Altjira } \\
\text { AltjirrallAltyerre }\end{array}$ & $\begin{array}{l}\text { Gott, der } \\
\text { Unerschaffene }\end{array}$ & God, the Uncreated One \\
$\begin{array}{lll}\text { Altjirangamitjina } & \text { Totem-Götter } & \text { Totem-Gods (the eternal } \\
\text { Altjirrangamatjinall } & \text { (die ewigen } & \text { Uncreated Ones) } \\
\begin{array}{l}\text { Altyerrengametyene } \\
\text { lit. 'from/in the } \\
\text { altjirrallaltyerre' }\end{array} & \text { Unerschaffenen) } & \text { Adreaming beings }\end{array}$ \\
\hline
\end{tabular}

There is of course a wealth of other information in the definitions in the dictionary which this discussion has only touched upon.

\section{Conclusion}

Strehlow's dictionary is a valuable historical resource that has made significant contributions to modern dictionaries of Arandic and Western Desert languages, and to other research. It was a remarkable personal achievement that came from Strehlow's intellect and training, and from the broader cultural description and translation work he also undertook. This chapter has examined Strehlow's dictionary from a linguistic perspective in order to understand his achievement, the nature and value of the work as it stands, and its potential contribution to future linguistic research and practical dictionaries. The details of his work will perhaps best be appreciated only when a historical dictionary of the Arandic languages is published. This will require careful interpretation of the entries, taking into account the nature of the dictionary as described in this chapter, and especially the detailed information which would need to be consistently made explicit in each entry. In the meantime, the presentation of the dictionary in this volume, and hopefully in a digital form, will be available for the study of Aranda language, culture and history.

14 Also note that he capitalises both Aranda words, apparently giving both concepts similar status. Most of the few other Aranda words capitalised in the dictionary are place names and interjections, and the remainder are a miscellaneous group. 
This text is taken from Carl Strehlow's 1909 Comparative Heritage Dictionary: An Aranda, German, Loritja and Dieri to English Dictionary with Introductory Essays, edited by Anna Kenny, published 2018 by ANU Press, The Australian National University, Canberra, Australia.

doi.org/10.22459/CSCHD.08.2018.05 